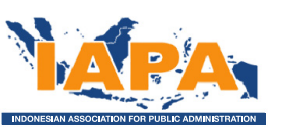

\begin{tabular}{r|l} 
POLICY\&GOVERNANCE & PGR
\end{tabular}

\author{
Ahmad Sururi \\ Public Administration Study Program, Faculty of Social Political and Law Sciences, Serang Raya University \\ Email: sururiahmad@unsera.ac.id
}

Submitted: 1 November 2019, Revised: 9 December 2019, Accepted: 8 January 2020

\section{Ahmad Sururi}

Lecturer and researcher in Public Administration, was born in Serang Banten, Indonesia, 20 January 1975. Graduated from the Faculty of Social and Political Sciences, STIA Maulana Yusuf Banten of Indonesia, with specialization on public administration. He obtained his Master of Administration Science from the University of Islam Syekh Yusuf Tangerang. His research interests in the areas of Public Sector, Public Policy, Urban Studies and Community Development. Since 2014, he has worked as a lecturer and researcher at the Public Administration Study Program,

Faculty of Social, Political and Law Sciences, Serang Raya University.

Policy \& Governance Review ISSN 2580-4820

Vol. 4, Issue 2, pp. 128-139

DOI: https://doi.org/10.30589/pgr. v4i2.216

\title{
Collaborative Governance Actor in the Revitalization Program of Old Banten Religious Tourism Area
}

\begin{abstract}
This study discusses the interactions of collaborative governance actors in the revitalization program of the Banten Religious Tourism Area. The purpose of this study is to show the factors that influence the cooperation of local governments as well as analysis of the interaction between local government in the Revitalization Program of the Banten Religious Area. The research method is qualitative descriptive with interview and observation data collection techniques. Data in this study were obtained through primary data and secondary data. The results showed that various factors such as commitment, identification of priority needs, the process of integration and harmonization, participatory and institutional models supported the success of regional cooperation in the revitalization program. The interaction between regional cooperation policy actors in the Revitalization Program of the Old Banten Tourism Area in Serang City at the implementation level has run well, although there are still problems, which include interactions that are indirectly influenced by systems such as politics, economic and social systems. Problems also include the behavior of elites and officials who lean on certain groups.
\end{abstract}

\section{Keywords:}

typology actors; collaborative governance; revitalization

\section{Introduction}

The policy of decentralization in the form of local autonomy in Indonesia, which guarantees regional autonomy privileges and their legal basis, is acknowledged in the Law Number 23 of 2014 about Regional Government. It is stated that regional autonomy is the right, authority and obligation of the autonomous region to regulate and manage their own government affairs and the interests of the local community in the system of the Unitary State of the Republic of Indonesia. The concept of decentralization by emphasizing the development of local and regional government capacity is seen as an effort as well as a starting point in developing regional autonomy. The Planning from the central government is not only complicated and difficult to apply, but may also 
be inappropriate to create equitable growth and independence among low-income groups or communities in developing countries (Rondinelli, Nellis, \& Cheema, 1983).

The implementation of development which focuses on efforts to reduce central government initiatives needs to be reduced by giving autonomy to local governments in decisionmaking and prioritizing the interests of planning development programs in the region. One of the efforts in achieving the success of development programs in the regions is to encourage collaborative governance. This is inseparable from the dynamics and public demands for quality regional development that can have an impact on society's welfare. Through local government cooperation based on considerations of synergy and mutual benefit, it is expected to create efficiency and effectiveness of public services (besides, collaborative governance becomes important). In addition, it is as a preference of the limitations possessed by each region in an effort to accelerate regional development goals.

The revitalization program of the old Banten religious tourism area involves the cooperation of various parties, namely Banten Provincial Government, Serang City Government, Serang Regency Government and Banten Cultural Conservation Agency (BPCB) listed in the Memorandum of Understanding (MOU). Collaborative governance policy is needed because of the lack of coordination between regional governments in the implementation of regional development, geographical and administrative similarities and authority over areas directly adjacent to the Banten religious tourism area in the use of natural resources and border areas. Therefore, based on these factors, collaborative governance is carried out. According to Scott \& Thomas (2016) public managers employ collaborative governance-as a process box and cooperation tool to achieve policy objectives. As a result, the decision to utilize resources through the process box and cooperation tools can be understood for strategic purposes.

Collaborative governance has become a general term in the public administration literature, which is described as a reaction to traditional planning and top-down oriented policy formulation approaches with a focus on technocratic oriented and unorganized governance. This notion fits perfectly with criticism of traditional Public Administration and the shift from government to government (Buuren, 2009b). In the past, government was the main driver in public policy (problemsolving, policymaking and service delivery), but now more actors are involved, from small nonprofit organizations at the local level to large multinational organizations where many groups have become an important part in the Goldsmith \& Eggers policy process (2004) in Sisto (2018). This requires a shift from traditional top-down ways of solving problems to more cooperative ways of solving problems, which are often referred to as a shift from government to governance (Klijn \& Koppenjan, 2016) as quoted in Sisto (2018).

Nevertheless, objectively, regional cooperation in the revitalization program of the Old Banten religious tourism area still faces various problems, such as the pattern and relationship between policy actors that are still not optimal. There is still overlapping authority between policy stakeholders, especially at the level of technical bureaucracy. There is also lack of visitor access to space public areas, such as unrepresentative parking areas, the slow process of relocation of street vendors (PKL) from sterile areas of religious tourism to the already provided areas, namely the Tourism Support Areas (KWP). It also involves the absence of zoning systems of cultural heritage areas as sterile place and historic sites that must be protected and preserved. Regional Regulation of Serang (Number 14 of 2014 concerning the Regional Tourism Development Master Plan for 2015-2025 article 11 paragraph 1 letter b) states 
that zoning arrangements and clear tourist traffic flows in each tourist attraction as an effort to protect locations that have historical value. It also preserves cultural heritage and other assets that have historical value, integrates parking facilities to serve the movement of tourists within the area, infrastructure development and completeness of roads that support the assistance of cultural heritage tourism areas, structuring and controlling space for relocation of street vendors and the construction of souvenirs and souvenir centers around the tourist area road. The formulation of the problem is to analyze the factors that influence the success of regional cooperation and how the interaction patterns of regional cooperation policy actors in the Revitalization Program of the Old Banten Religious Tourism Area in Serang City is.

\section{Literatur Review \\ Collaborative Governance}

For more than two decades, the collaborative governance system has attracted the attention of academics and practitioners in various disciplines. Collaborative governance has become a popular topic in the field of Public Administration and much of the literature has been dedicated to research (Ansell \& Gash, 2007; Ali-khan \& Mulvihill, 2008; Buuren, 2009; Emerson \& Nabatchi, 2015; Morse et al., 2011; Matei \& Irimia, 2014; Doberstein, 2016; Rigg \& Mahony, 2013; Amsler, 2016; Emerson \& Gerlak, 2018). In line with this, collaborative governance has also become a popular topic in public policy and public management literature (Scott \& Thomas, 2016). Collaborative approaches (such as public-private partnerships, multi-sectoral publicpolicy networks, networks, and multi-stakeholder networks) are increasingly recommended for structuring greater government and addressing complex social and political problems, such as the environment and natural resources (Cash et al., 2006; Sandstr \& Bj, 2017).

Collaborative Governance is a regulation in which one or several public institutions directly involve formal stakeholders in a collective, consensus-oriented, and deliberative decisionmaking process and aims to create or implement public policy programs or public assets (Emerson, Nabatchi, \& Balogh, 2011). This means the role of the government is no longer provider, but facilitator and policymaker. The role of government will be effective if the output of public policies can adapt and innovate on various changes to encourage cooporation between various interests (Sururi, 2018). However, collaboration generally starts with instrumental goals, some of which have very broad goals. For example, in some locations, agents conduct social cooperation and joint economic development strategies with the aim of providing direction for individuals to collaborate (Huxham, Vangen, \& Eden, 2007)

According to Howlett, Ramesh, Weimer and Vining, in principle, policy actors are those who are always and must be involved in every process of public policy analysis, both functioning as formulators and pressure groups that are always active and proactive in carrying out interaction and interrelation in the context of public policy analysis (Rijal, Madani, \& Fatmawati, 2013). Furthermore, Mukhlis, Nazsir, Rahmatunnisa, \& Yani Yuningsih (2018), in their research, concluded that the dominance of policy actors in a program has an important and beneficial role even though it must be prevented. However, the dominance of actors provides benefits when not interpreted as an intervention, but as a greater role due to the ability and resource factors in the framework of a sustainable cooperation process. In other studies, Rutland \& Aylett (2008) suggest conducting analysis through the Actor-NetworkTheory (ANT) theory approach and governance. The first approach offers an understanding of how actors act collectively and the second approach is how the state tries to achieve its goals by directing people's behavior.

The challenge of collaborative governance concludes that there are several considerations 
in achieving goals and at least two factors influence the success of cooperation, namely the dimensions of complexity and structural diversity (Huxham et al., 2007). In addition, Siddiki, Kim, \& Leach (2017) said that there are at least ten partnership cooperation policies that provide recommendations on fisheries policies. The results showed that the diversity of beliefs among the participants was positively related to relational learning and the high trust supported a positive impact on rational learning. Based on two things in support of programs that are instructional, the capacity and learning cooperation can explain that the program runs in an integrated manner with diverse rules (Emerson \& Gerlak, 2018).

According to Ansell \& Gash (2007) collaborative governance is a type of governance in which public and private actors work collectively in different ways and use certain processes to establish laws and rules for the provision of public goods. Meanwhile, there are many forms of collaboration involving non-governmental actors. The researchers define specific roles for public institutions, using the term "public body." The concern is to include public institutions such as bureaucracy, courts, legislative bodies, and other government bodies in local and state level. Next, Ansell and Gash outlined six criteria, namely: 1) forums are initiated by public institutions, 2) participants in the forum include actors outside government, 3) participants are directly involved in decision-making and are not merely "consulted" by public bodies, 4) the forum is officially held and meets collectively, 5) the forum aims to make decisions based on consensus, and 6) the focus of collaboration is on public policy or public management (Ansell \& Gash, 2007).

Torfing et. al explain six dimensions of the effectiveness of collaborative governance assessments: (1) understanding policy problems and opportunities; (2) producing innovative, proactive and feasible policy options; (3) shared policies; (4) ensuring the smooth implementation of the policy; (5) flexible adjustments to policy solutions; (6) creating favorable conditions for future cooperation (De Boer, Franco, Moonen, \& $\mathrm{Wu}, 2017$ ). Plotnikof (as cited in Mukhlis et al., 2018) states that the role of managers stressed the implicit challenges in collaborative governance: social dynamics concerning ambiguity and complexity of membership, relationship of tension between stakeholders, and domination of formal power structures.

The dominance of actors in collaborative governance research conducted by Mukhlis et al. (2018) shows that (1) the relationship between actor dominance and the level of trust, conflict, and policy success or failure is actually confirmed but does not have a negative effect directly; (2) the dominance of one of the actors is still needed in the collaboration process to ensure that the collaboration process can continue, because domination is different from intervention. In conclusion, the dominance of actors is ambivalent; something that must be prevented but then becomes a key factor. Furthermore, Sururi (2018) states that collaborative governance can be developed into an innovation policy model consisting of four important components, namely: existing conditions, commitment, institutional design, and final conditions.

\section{Methods}

This research uses a qualitative descriptive approach. A qualitative approach is used to describe the reality on the ground and to get the accuracy of the facts with the right interpretation. This research was conducted in March 2018 to September 2018. Data in this study were obtained through primary and secondary data. Primary data were collected through non-participant observation and interviews through direct interaction with key informants determined using purposive sampling techniques with such selection criteria. The selection of informants is based on subjects who have a lot of information 
related to the problem under study and are willing to provide information. Secondary data was collected through various data searches from various literature, such as journals, books, printed and electronic media to support data analysis. Furthermore, the data is explained in the form of narrative data.

Qualitative data analysis began by interviewing informants and studying various documents related to the object of research before interpreting and reporting the results together. Every information obtained by informants in oral and written form was studied comprehensively. This research does not only aim to uncover the truth but also to understand the truth. The last stage is to provide an analysis of how the interaction of collaborative governance policy actors in the revitalization program of the old Banten religious tourism area is.

\section{Results and Discussion}

\section{Factors Affecting the Success of Collaborative Governance}

The revitalization program of the old Banten religious tourism area involves three core elements of regional government, namely Banten Province, Serang City Government and Serang Regency. The revitalization program was initially the authority of the Serang City Government as the regional and administrative authority of the old Banten region, but in subsequent developments the handling of the revitalization program involved the Banten Provincial Government and the Serang Regency Government. Koontz et al. (as cited in Scott \& Thomas, 2016) identified three general roles played by public actors in collaborative governance. They can act as (i) leaders, directing collaborative governance initiatives; (ii) encouragement, providing human, financial or technical resources to accelerate or support collaborative governance; or (iii) followers, joining collaborative governance efforts organized or encouraged by others.
The idea received support from various parties including the community around the Old Banten religious tourism area. This form of community support can be seen from various participatory activities in various activities initiated by the regional government, such as the Banten Bebersih (Arbi, 2017). The activity was initiated by Banten Governor Wahidin Halim - Banten Deputy Governor Andika Hazrumy together with Serang Mayor and Serang Regent together with the community. The purpose of the "Banten Bebersih" movement is to clean up sorrounding religious tourism areas. Furthermore, the activity is to consolidate forum activities as the first step in revitalizing the religious tourism area and to become a program launching socialization activity.

The results showed that the implementation of the program process carried out by the community positively responded to the revitalization program in the hope that the program could have benefits in improving economic and social aspects in a sustainable manner. In addition, it can be stated based on the results of interviews that policy actors play an important role in encouraging successful cooperation between local governments. The collaborative governance literature shows that collaboration can build trust between stakeholders so people are more willing to exchange and receive information. In this case, cooperation has given its role. By staying in one table and talking to each other, participants can move to other participants by hiding information and adopting information based on values (Ulibarri, 2019).

The policy actors were represented through the leadership of the Governor of Banten Province, the Regent of Serang and the Mayor of Serang who have a commitment in operating the work plans and revitalization programs of the Old Banten religious tourism area. The results of observations and subsequent interviews conducted by researchers about how the important role of policy actors in 
building cooperation between local governments shows that the common understanding and views of the revitalization program are decisive factors, both the similarity of views on vision and mission as well as the agreement contained in the Memorandum of Understanding (MOU) of the Banten religious tourism revitalization program. In addition, it was stated that an appropriate and egalitarian dialogue instrument would determine the pattern of relations between policy actors or the leadership style of regional heads in decisionmaking. This confirms what has been stated by Trygg (2018), that the most important trigger for collaborative governance is leadership. The leader in one of the organizations is an actor who will take the initiative to solve problems in cooperation. How communication develops among actors over time will have an impact on collaborator dynamics. Unexpected actions will occur if the communication is ineffective.

Then related to how the patterns of interaction of policy actors, based on the results of interviews can be explained that equality and trust between policy stakeholder actors is the first key factor in cooperation between regions. By these principles, the actors interact in an egalitarian atmosphere that the design of the cooperation strategy must be informed by appreciation and trust because conflict is the main driving factor in the occurrence of different strategies that can affect the level of success. Public officials seem to be able to estimate precisely the level of social trust among stakeholders.

When public officials choose collaboration strategies that are in accordance with perceptions of trust among stakeholders, the results tend to be better and policy objectives are then implemented to a greater extent (Zachrisson, Bjärstig, \& Eckerberg, 2018). According to Charlie et al. (as cited in Kossmann, Behagel, \& Bailey, 2016) there are two types of collaborative governance networks: (1) action-oriented networks where the initiative originates from private or community institutions involved with the aim of producing collaborative actions to overcome problems, and (2) the policy and planning network where the public or government agency starts collaboration by coordinating relationships with other stakeholders such as NGOs, business owners and local communities with the aim of developing and implementing plans.

The hierarchical difference between provinces, districts and cities is not an obstacle in establishing cooperative relations. Building equality by not looking at hierarchical and structural boundaries can have implications for mutually beneficial cooperation amid the limitations of each provincial government and of each district and city local government. Nevertheless, researchers found that there are still patterns and communication relationships that are rigid and prioritize structural ego and service at the technical level between policy actors within the institutional and service scope and between policy actors with the target of policy objects, namely Street Vendors (PKL) ) and community. Collaborative governance can be fragile, timeconsuming, risky and can lead to failure. When it fails, it can lead to skepticism and conflict, and when it is successful, it is often caused by contextual factors such as leadership or external environmental conditions (Ansell \& Gash, 2018).

Furthermore, the research findings also show that there are still obstacles in the process of relocation of street vendors from a sterile area of a Religious Tourism Area (KWR) to a Supporting Tourism Area (KPW) that has been provided. The attraction of interest between the local government and street vendors becomes an obstacle to the relocation process. The street vendors consider the KPW area to be less strategic for tourists to come to visit so that it is economically unprofitable because it is far from the main location of the Old Banten religious tourism area. Besides that, disharmony between policy actors at the technical level can 
be seen from the overlapping of decision-making, which is due to the lack of understanding of the bureaucracy at the technical level in operating the policy. Moreover, it is due to different policy actors responding to policy problems, negotiation and public administrators design, as well as collaborative governance to achieve collaborative excellence.

The results of this study also clarify research findings conducted by Doberstein (2016), which say that by understanding how policy actors interact in collaborative governance, we must look at the participation and contribution of these actors. Therefore, one of the priority policies, to support the success of collaborative governance is to encourage participants to be directly involved in the revitalization program. With the pattern of participation and the contribution of relationships based on the position of equal policy actors without a rigid hierarchy, it is expected to create cooperation between the regional government of cooperation and mutual symbiosis. A starting point for understanding that policy actors are individuals or organizations who take action and are able to influence the outcome of the decision results, tend to focus on goals and solutions to overcome problems. In a result, they can be a solution in the process of interaction with other policy actors (Zaman, 2007).

Citizen participation is a complex process that is contested and limited to the space of citizenship that cannot be accessed equally. Citizenship is influenced by a number of local political and socio-cultural factors such as history, religion, ethnicity, language, culture and economy. However, a collaborative governance model with a public-private partnership structure, has provided opportunities for minority citizens to get a voice in reshaping urban space on a local scale (Ghose, 2005), and encouraging changes in organizational culture to better understand collaborative governance must continue. In addition to changing the culture of the organization, other suggestions include broadening the analysis that leads to the decision to collaborate or not, to include factors such as the context, goals or mission of the collaboration, member selection and capacity development, motivation and commitment of collaborators, collaboration structure and governance, strengths in collaboration, accountability, communication, perceived legitimacy, trust, and information technology (Leary, 2014).

\section{Interaction of Policy Actor in Collaborative Governance}

Interaction of policy actors is understood as a pattern of communication carried out by policy actors together in a policy network. According to Stone (as cited in Madani, 2011) there are four types of interactions in the use of actor power between institutions, namely: First, Decisional, interactions which are formed due to the use of power or authority possessed by each group involved to fight for their interests. This interaction can also occur because of interest groups such as businesses that directly provide support to certain parties or groups during elections or campaigns; in this case the revitalization program of the Old Banten religious area was implemented based on the authority possessed by each local government. In addition, the revitalization program was not meant as the end of the policy but was an ongoing program.

As stated by Zaman (2007) in his research, it is reasonable to assume that the goals of policy actors are directly related to their interests, whether it is to earn money, enhance their reputation or to implement values that contribute to the definition of their identity.

The financial support policy of the Banten Provincial Government sourced from the Banten Province APBD (Regional Budget) in the revitalization program shows that there is an appropriate decisional amid the limited funds owned by the City and Serang District Governments 
in completing the revitalization program. The reason behind the regional cooperation is the limitation of government resources; the government does not have all the information, power and budget needed for environmental management, so it depends on other stakeholders (Huxham et al., 2007).

Second, Anticipated Reaction, interaction that is direct but formed due to the structure of power and control over resources in certain situations. The magnitude of the potential and local resources of Old Banten, which are geographically located in three regional government areas, led to the idea of cooperation as stipulated in the Memorandum of Understanding (MOU). The same importance factor for the mastery of local resources in Old Banten forms the interaction of policy stakeholders to be stright and open. Policy actors interact in carrying out revitalization programs based on their vision and mission in accordance with the MOU so that decision-making is based on anticipatory steps and interactive reactions.

Third is Non-Decision Making, interactions that are identified as having a strong group or majority trying to influence policy. This type of interaction can also involve a third-party or external to support one of the policy actors. These external influences become part of the power and interests of the elite. Even though it is characterized as an external party with strong authority (Banten Provincial Government and Serang Regency), the interaction is still within the limits of authority. The interaction of non-decision actors is precisely at the technical level when making the decision to relocate street vendors (PKL) from a sterile area of the Religious Tourism Area (KWR) to the Tourism Support Area (KPW). In this case there is a tendency for street vendors to try to influence one of the policy actors to side with the interests of street vendors so that it causes a tug of war between the local government and street vendors resulting in an obstacle to the relocation process.
Fourth is Systemic, interactions that are indirectly influenced by systems such as political, economic and social systems. This is identified through the behavior of elites and officials who favor certain interest groups. In this type of interaction, the use of power is carried out by three groups or actors who place public officials in the middle position. Indirect interactions are marked by interactions between interest groups who seek to influence the policy elite with the aim that their interests can become policy choices. On the one hand, the use of support from interest groups is considered strategic by the policy elite to strengthen the priority of policy choices.

Factors of economic, social and political importance in the process of regional cooperation between the Provincial Government of Banten, the District Government of Serang and the City Government of Serang have led to the interaction of policy actors that have not been harmonious. As explained in the results of the study, disharmony still exists between policy actors at the technical level. It can be seen from the lack of understanding in operationalizing policy technically so that overlapping occurs in decision-making. This is due to the support of strategic groups from the elements of society and policy actors such as street vendors and tourism area managers. If the street vendors group support is stronger, it can provide economic benefits. It conflicts the support of the group from the manager of the religious tourism area (KWR) who tends to support the Serang City government as a policy actor who has been conducting coaching towards them.

The four models of interaction of policy actors show weaknesses, namely the absence of alternative policies or decision-making from policy actors in dealing with problems at the technical or operational level of the policy. Therefore, researchers modify the theory by adding the type of interaction, namely dynamic decision as an alternative for policy actors in dealing with problems that require decisions that 
are dynamic and require the urgency of solving problems.

Figure 1.

Interaction Types of Policy Actors

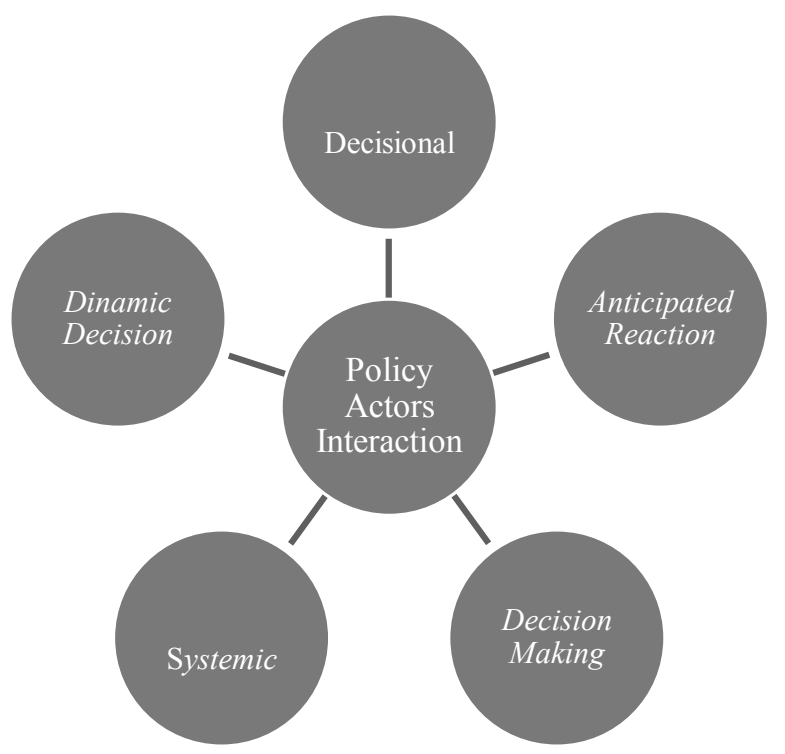

Source: Adapted by the writer, (2019)

Types of dynamic policy interactions are needed as an alternative to decision-making when the four previous types of interactions experience deadlock in decision-making. Dynamic decisions involve choices made in an environment that can change exogenously or as a function of previous choices where decisions are connected sequentially to each other so that the impact of an action at a particular time directly or indirectly influences future actions (Gonzalez, Fakhari, \& Busemeyer, 2017). It can be argued that dynamic decisions are not focused on only one activity but on several objectives (Brehmer, 1992).

Therefore, dynamic decisions require flexibility in each process and stage, especially for approaches that involve policy actors and public participation so that they are expected to be able to overcome the complexity of the problem of revitalizing the Old Banten Religious Tourism Region. Identification of public participants requires three conditions that are key to developing a shared agenda, namely: (a) focus on the problem being targeted; (b) champions to drive the process, provide support and ensure inclusiveness; and (c) members' willingness to "stay on the table." Narrowing the focus of the initiative is seen as an important fact (Salignac, Wilcox, Marjolin, \& Adams, 2018). Furthermore, participants have a strong view of what they believe to be a key success factor, and this forms three broad categories. In the end, it can be concluded that the type of interaction of dynamic decisions can be the preference of policy actors and public participation in collaborative governance for strategic decision-making.

The results of research conducted by Fliervoet \& Born (2016) states that the achievement of collaborative governance undertaken by policy actors from the government bureaucracy needs to develop the ongoing cooperative relationships and require time and effort and recognition of actors outside the government as partners cooperation. The results of the study conducted by Ran \& Qi (2018) state that exploring sources of strength and mutual trust in collaboration can contribute to the formation of collective goals, group consensus and shared values, increased participant compliance with other partners, and increased collaboration legitimacy.

Based on the explanation of the results and discussion described above, the expected implication of this research is the sustainability of regional cooperation by developing policy innovations and encouraging regional cooperation bodies that can solve problems together. In addition, the context of decision-making needs a dynamic mechanism through decision-making to solve technical problems.

\section{Conclusion}

The success of regional cooperation is influenced by four important factors, namely the commitment of regional leaders, identification of priority needs, the process of integration and harmonization, and participatory and institutional 
models. These factors as a whole are preferences for policy actors in supporting the success of collaborative governance. The results showed that the problematic factor was the absence of an analysis of the identification of needs that were the priority of the policy and the importance of encouraging an institutional model in the form of a body or forum that could become the leading sector in a sustainable revitalization program.

Typology of interaction between regional cooperation policy actors in the Revitalization Program of the Old Banten Religious Tourism Area in Serang City at the level of implementation was analyzed through four types of interactions, namely Decisional, Anticipated Reaction, NonDecision Making and Systemic. Of the four types of interactions, non-decision making and systemic interaction at the implementation level still encounters problems where there are interactions which are indirectly influenced by political, economic and social systems. This is identified through the behavior of elites and officials who favor certain interest groups. Therefore, a type of dynamic policy interaction (dynamic decision) is needed as an alternative to decision-making when the four previous types of interaction experience deadlock in decision-making.

\section{References}

Ali-khan, F., \& Mulvihill, P. R. (2008). Exploring collaborative environmental governance: Perspectives on bridging and actor agency. Geography Compass, 2(6), 1974-1994. doi: 10.1111/j.1749-8198.2008.00179.x

Amsler, L. B. (2016). Collaborative Governance: Integrating Management, Politics, and Law. Public Administration Review, $x x, 1-12$. doi: 10.1111/puar.12605.Collaborative

Ansell, C., \& Gash, A. (2007). Collaborative governance in theory and practice. Journal of Public Administration Research and Theory, 18(4), 543-571. doi: 10.1093/ jopart/mum032
Ansell, C., \& Gash, A. (2018). Collaborative Platforms as a Governance Strategy. Journal of Public Research And Theroy, 16-32. doi: 10.1093/jopart/mux030

Arbi, A. (2017, September 21). Bebersih Banten Lama. Radar Banten. Retrieved from https://www.radarbanten.co.id/bebersihbanten-lama/

Brehmer, B. (1992). Dynamic decision making: Human control of complex systems*. Acta Psychologica, 81, 211-241.

Buuren, A.van. (2009a). Knowledge for Governance, Governance of Knowledge: Inclusive Knowledge Management in Collaborative Governance Processes. International Public Management Journal, 12(2), 208-235. doi: $10.1080 / 10967490902868523$

Buuren,A.Van. (2009b). Knowledge for governance, governance of knowledge: Inclusive knowledge management in collaborative governance processes knowledge: Inclusive knowledge management. International Pubic Mangement Journal, (December 2014), 37-41. doi: 10.1080/10967490902868523

Cash, D. W., Adger, W. N., Berkes, F., Garden, P., Lebel, L., \& Olsson, P. (2006). Scale and Cross-Scale Dynamics : Governance and Information in a Multilevel World. Ecology and Society, 11(2).

De Boer, T., Franco, J., Moonen, F., \& Wu, J. (2017). Towards a sustainable future: Lessons for local collaborative governance. Utrecht. Retrieved from https://www.hieropgewekt. $\mathrm{nl} /$ uploads/inline/Report Towards a sustainable future - Utrecht School of Governance.pdf

Doberstein, C. (2016). Designing collaborative governance decision-making in search of a 'Collaborative Advantage.' Public Management Review, 18(6), 819-841. doi: 10.1080/14719037.2015.1045019

Emerson, K., \& Gerlak, A. K. (2018). Teaching collaborative governance online: Aligning 
collaborative instruction with online learning platforms. Journal of Public Affairs Education, 22(3), 327-344. doi: $10.1080 / 15236803.2016 .12002251$

Emerson, K., \& Nabatchi, T. (2015). Evaluating the productivity of collaborative governance regimes: A performance matrix. Public Performance and Management Review, 38(4), 717-747. doi: 10.1080/15309576.2015.1031016

Emerson, K., Nabatchi, T., \& Balogh, S. (2011). An Integrative Framework for Collaborative Governance.Journal of Public Administration Research and Theory, (June 2009), 1-29. doi: 10.1093/jopart/mur011

Fliervoet, J. M., \& Born, R. J. G. Van Den. (2016). From implementation towards maintenance : sustaining collaborative initiatives for integrated floodplain management in the Netherlands From implementation towards maintenance: sustaining. International Journal of Water Resources Development, 0627(August). doi: 10.1080/07900627.2016.1200962

Ghose, R. (2005). The complexities of citizen participation through collaborative governance. Space and Polity, 9(1), 61-75. doi: 10.1080/13562570500078733

Gonzalez, C., Fakhari, P., \& Busemeyer, J. (2017). Dynamic Decision Making: Learning Processes and New Research Directions. Human Factors, 59(5), 713-721. doi: $10.1177 / 0018720817710347$

Huxham, C., Vangen, S., \& Eden, C. (2007). The Challenge of Collaborative Governance. Public Management: An International Journal of Research and Theory, 2(3), 337358. doi: 10.1080/14719030000000021

Kossmann, C. M., Behagel, J. H., \& Bailey, M. (2016). Action and inertia in collaborative governance. Marine Policy, 72, 21-30. doi: 10.1016/j.marpol.2016.06.007
Leary, R. O. (2014). Collaborative governance in New Zealand: Important choices ahead prepared by. New Zealand: Fulbright New Zealand.

Madani, M. (2011). Dimensi interaksi aktor dalam proses perumusan kebijakan publik. Yogyakarta: Graha Ilmu.

Matei, A., \& Irimia, S. I. (2014). Open source governance-A more ambitious cousin of collaborative governance. International Journal of Public Administration, 37(12),812823. doi: 10.1080/01900692.2014.907315

Morse, R. S., Mckinney, M. J., \& Johnson, S. (2011). The Practice of Collaborative Governance. Public Administration Review, 953.

Mukhlis, M., Nazsir, N., Rahmatunnisa, M., \& Yani Yuningsih, N. (2018). The Actor Domination in the Collaborative Governance in the Lampung Province Central Government Displacement Policy: An Ambivalent. Jurnal Ilmiah Peuradeun, 6(3), 507. doi: 10.26811/ peuradeun.v6i3.272

Ran, B., \& Qi, H. (2018). The entangled twins: Power and trust in collaborative governance. Administration \& Society, 1-30. doi:10.1177/0095399718801000

Rigg, C., \& Mahony, N. O. (2013). Frustrations in collaborative working. Public Management Review, 15(1), 84-108. doi: 10.1080/14719037.2012.686231

Rijal, F., Madani, M., \& Fatmawati. (2013). Interaksi aktor dalam perumusan kebijakan pengelolaan pertambangan di Kabupaten Kolaka Utara. Otoritas : Jurnal Ilmu Pemerintahan, III(2), 14-26.

Rondinelli, D. A., Nellis, J. R., \& Cheema, G. S. (1983). Decentralization in developing countries. The International Bank for Reconstruction and Development/The World Bank Washington D.C., U.S.A.

Rutland, T., \& Aylett, A. (2008). The work of policy: Actor networks, governmentality, and 
local action on climate change in Portland, Oregon. Environment and Planning D: Society and Space, 26(4), 627-646. doi: $10.1068 / \mathrm{d} 6907$

Salignac, F., Wilcox, T., Marjolin, A., \& Adams, S. (2018). Understanding Collective Impact in Australia : A new approach to interorganizational collaboration. Australian Journal of Management, 43(1), 91-110. doi: 10.1177/0312896217705178 Sandstr, C., \& Bj, T. (2017). Public-private partnerships in a Swedish rural context - A policy tool for the authorities to achieve sustainable rural development ?. Journal of Rural Studies, 49, 58-68. doi: 10.1016/j. jrurstud.2016.11.009

Scott, T. A., \& Thomas, C. W. (2016). Unpacking the collaborative toolbox: Why and when do public managers choose collaborative governance strategies?. Policy Studies Journal, 00(00), 1-24.

Siddiki, S., Kim, J., \& Leach, W. D. (2017). Diversity, trust, and social learning in collaborative governance. Public Administration Review, 77(6), 863-874. doi: 10.1111/puar.12800

Sisto, D. (2018). The influence of collaborative governance processes on the performance of Blue Green Infrastructure projects in the maintenance phase within Dutch cities. Interreg North Sea Region Erasmus Universiteit Rotterdam.

Sururi, A. (2018). Collaborative Governance Sebagai Inovasi Kebijakan Strategis (Studi Revitalisasi Kawasan Wisata Cagar Budaya Banten Lama). Humanika, 25(1). doi: 10.14710/humanika.v25i1.18482

Trygg, K. (2018). Understanding collaboration and local development-a Swedish case study on different actors' roles and perspectives. Scottish Geographical Journal, 134(3-4), 172-183. doi: 10.1080/14702541.2018.1471156

Ulibarri, N. (2019). Collaborative governance : a tool to manage scientific, administrative , and strategic uncertainties in environmental management?. Ecology and Society, 24(2).

Zachrisson, A., Bjärstig, T., \& Eckerberg, K. (2018). When public officers take the lead in collaborative governance: To confirm, consult, facilitate or negotiate?. Scandinavia Journal of Public Administration, 22(4), 21-44.

Zaman, A. (2007). Understanding Policy (1st ed.). Islamabad: Pakisran Institute Development. 